\title{
A COMPARATIVE STUDY OF INNOVATION-BASED AND IMITATION-BASED ECONOMIES IN THE ERA OF THE FOURTH INDUSTRIAL REVOLUTION
}

\author{
Julianna Csugány ${ }^{1}$
}

DOI: https://doi.org/10.31410/ERAZ.2019.303

\begin{abstract}
Nowadays, we live in the era of the Fourth Industrial Revolution, in which the digitization, automatization and robotization process enabling the wider use of information and communication technologies reorganizes the operation of the economies. In previous research, innovation- and imitation-based economies have been classified using multivariate statistical methods to highlight the duality of technological progress. The Fourth Industrial Revolution offers an opportunity to reorganize global power relations; innovation followers can become innovation leaders due to new technologies, as well as, innovation leaders can lag behind without innovation. The World Economic Forum creates the new Global Competitiveness Index 4.0 which measures the relevant components of competitiveness in 140 countries in the era of the Fourth Industrial Revolution. This research aims to compare the economic performance of innovation- and imitation-based economies in the relevant field of technological progress based on GCI 4.0 using multivariate statistical methods.
\end{abstract}

Keywords: The Fourth Industrial Revolution, innovation-based economies, imitation-based economies, Global Competitiveness Index 4.0.

\section{INTRODUCTION}

$\mathrm{N}^{2}$ owadays, we live in the era of the Fourth Industrial Revolution, when new technologies fundamentally change the operation of the economy. Digitization creates opportunities to improve economic efficiency which lead to productivity and economic growth. Technological changes are more complex and realize faster as before. Several empirical studies (e.g. [1], [2], [3], [5]) confirm that the higher-income countries are typically technologically more advanced, their innovation activity is more intensive and they create the majority of the innovations, in contrast to the lower-income countries, which are typically technology followers, and can adapt new technologies through the imitation of technological leaders. Based on this, technological progress happens in different ways in different countries of the world, depending on their income levels. In [7] Szalavetz pointed out that the relationship between innovation and growth is different depending on the distance from the technology frontier. Most countries of the world imitate, so technological progress is based on technology import and imitation, and there are only a few countries where innovations are created, which, therefore, may be regarded as true innovators. In the previous study ([4]), 139 countries were divided into two groups, innovation-based economies, where innovation activity is high, and imitation-based economies, where the innovation is not as important as in the other group. The theoretical basis of this classification was the concept of the World Technological Frontier which is capable to differentiate countries based on their technical, human and economic characteristics. We differentiated innovator and imitator countries with cluster analysis based on a novel indicator, technological-institutional environment index and GDP per capita. This classification can be used to compare the innovation activities of innovation performance groups in the era of the Fourth Industrial Revolution. This research aims to make a comparative study of innovation-based and imitation-based countries using the Global Competitiveness Index 4.0 created by the World Economic Forum.

Eszterházy Károly University, Eger, Hungary 


\section{RESEARCH QUESTION, METHODOLOGY}

It is assumed that the economic performance of innovation-based countries is better than imitation-based ones in almost every field of competitiveness. Because of this, the research question is in which areas of the Global Competitiveness Index 4.0 there are no significant differences between innovation-and imitation-based economies. It is also important in which area there is the main difference between country groups. The new wave of technological progress creates an opportunity of reducing the technology gap between countries so we also try to answer the question of whether imitation-based economies seem to be converged to innovation leaders. The components of the Global Competitiveness Index 4.0 are compared in innovation- and imitation-based economies using parametric and non-parametric statistical methods.

The 2018 edition of the Global Competitiveness Report created by the World Economic Forum presents the Global Competitiveness Index 4.0 which is the set of drivers of productivity and long-term growth in the era of the Fourth Industrial Revolution. There are twelve pillars of the new index grouped into four main categories and includes 98 indicators (Figure 1). The structure of this new index is different from the previous ones, 34 variables have been retained from the previous methodology while 64 indicators are new.

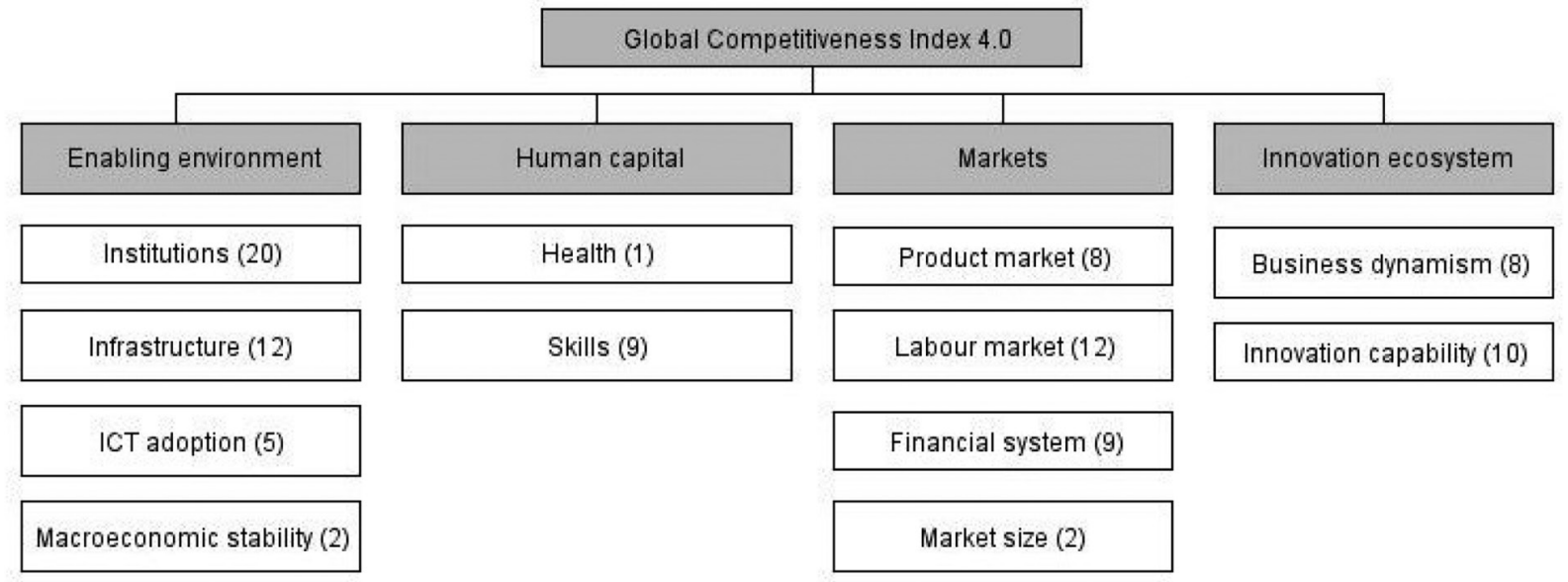

Figure 1: The composition of Global Competitiveness Index 4.0

Source: own construction based on [6]

According to the Global Competitiveness Index 4.0, there are four main categories which are required to a country becomes competitive in the era of the Fourth Industrial Revolution. The enabling environment includes variables from the field of institutions, infrastructure, ICT adoption, and macroeconomic stability. Most variables are in this group because these ones create the basic conditions of realizing technological progress which leads to competitiveness. The other important category is the human capital, mainly the skills as well as the indicators of the quantity and quality of human resources. Markets are necessary to acquire resources and essential for a successful business operation which leads to a firm becomes competitive not only in domestic but also in the international market. The fourth group is the innovation ecosystem which focuses on the innovative activities and their efficiency.

In this analysis, there are 131 countries, 23 innovation-based economies and 108 imitation-based countries. This classification is based on the previous research ([4]). Innovation-based economies are Australia, Austria, Belgium, Canada, Denmark, Finland, France, Germany, Iceland, Ireland, 
Israel, Japan, Luxembourg, the Netherlands, New Zealand, Norway, Qatar, Singapore, Sweden, Switzerland, United Arab Emirates, United Kingdom, United States. Imitation-based economies are Albania, Algeria, Angola, Argentina, Armenia, Azerbaijan, Bahrain, Bangladesh, Benin, Bolivia, Bosnia and Herzegovina, Botswana, Brazil, Bulgaria, Burkina Faso, Burundi, Cambodia, Cameroon, Cape Verde, Chad, Chile, China, Colombia, Costa Rica, Cote d'Ivoire, Croatia, Cyprus, Czech Republic, Dominican Republic, Ecuador, Egypt, El Salvador, Estonia, Ethiopia, the Gambia, Georgia, Ghana, Greece, Guatemala, Guinea, Haiti, Honduras, Hungary, India, Indonesia, Iran, Islamic Rep., Italy, Jamaica, Jordan, Kazakhstan, Kenya, Korea Rep., Kuwait, Kyrgyz Republic, Latvia, Lebanon, Lesotho, Lithuania, Macedonia, FYR, Malawi, Malaysia, Mali, Malta, Mauritania, Mauritius, Mexico, Moldova, Mongolia, Montenegro, Morocco, Mozambique, Namibia, Nepal, Nicaragua, Nigeria, Oman, Pakistan, Panama, Paraguay, Peru, Philippines, Poland, Portugal, Romania, Russian Federation, Rwanda, Saudi Arabia, Senegal, Serbia, Seychelles, Sierra Leone, Slovak Republic, Slovenia, South Africa, Spain, Sri Lanka, Tanzania, Thailand, Trinidad and Tobago, Tunisia, Turkey, Uganda, Ukraine, Uruguay, Vietnam, Yemen, Zambia, Zimbabwe.

Using parametric and non-parametric tests, the performance of country groups is compared to highlight the significant differences between innovation- and imitation-based countries. Firstly, the normal distribution of variables is tested using Kolmogorov-Smirnov test. If a variable has a normal distribution, $t$ test is used to compare the means of country groups. In other cases, when there is no normal distribution, Mann-Whitney U test is used.

\section{EMPIRICAL RESULTS}

As a first step in the analysis, innovation- and imitation-based countries are compared in the twelve pillars of Global Competitiveness Index 4.0 (see Figure 2). The highest difference between country groups is in the innovation ecosystem followed by enabling environment and human capital, while in markets they are not so far from each other.

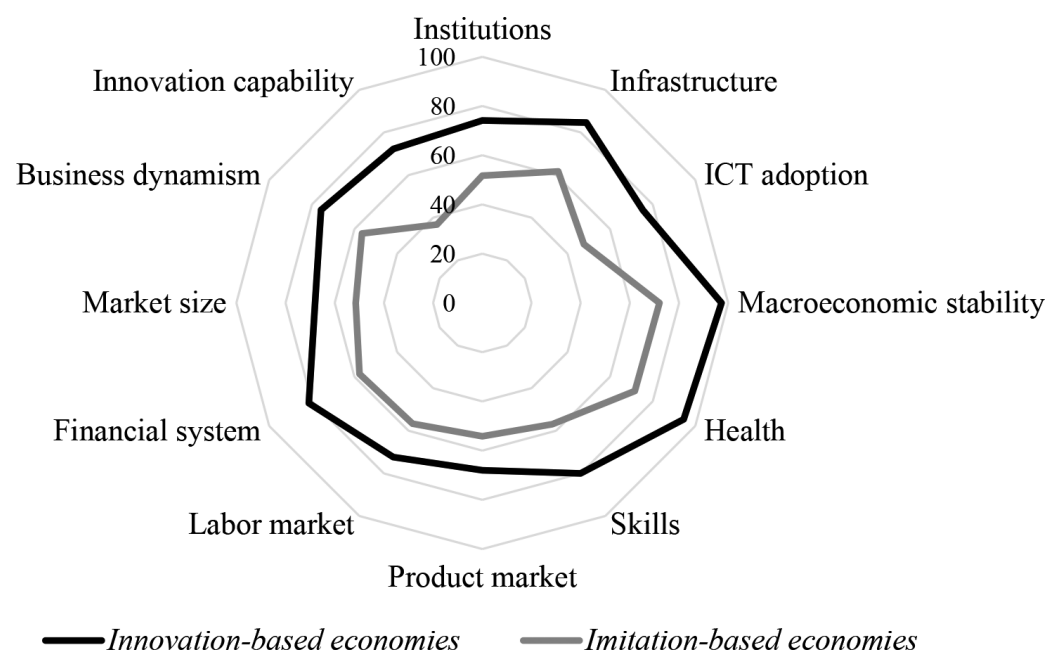

Figure 2: Differences between innovation-based and imitation-based economies in the twelve pillars of the Global Competitiveness Index 4.0

Source: own calculations based on [8]

Figure 2 shows that the main difference between innovation- and imitation-based economies is in the field of innovation capability and the performance groups are close to each other in the field of product and labour market. In the innovation capability pillar, there are 10 variables. 
The highest difference is in IP5 international patent applications (per million pop), in innovation-based economies, the number of international patent applications is more than 25 times higher than in imitation-based economies. The number of the patent application is more than 19 times higher; the trademark applications are only more than 5 times, while the scientific publications $H$ Index is about 4 times higher in innovation-based countries than in imitation-based ones. Based on these results, we can conclude that there is a significant difference in innovation output between innovation performance groups. However, the patent and trademark protection are not as important as some years ago, because these forms of property right protection do not fit for the rapid technological changes. Figure 3 shows the difference between country groups in the seven-stage scale variables of the innovation capability pillar.

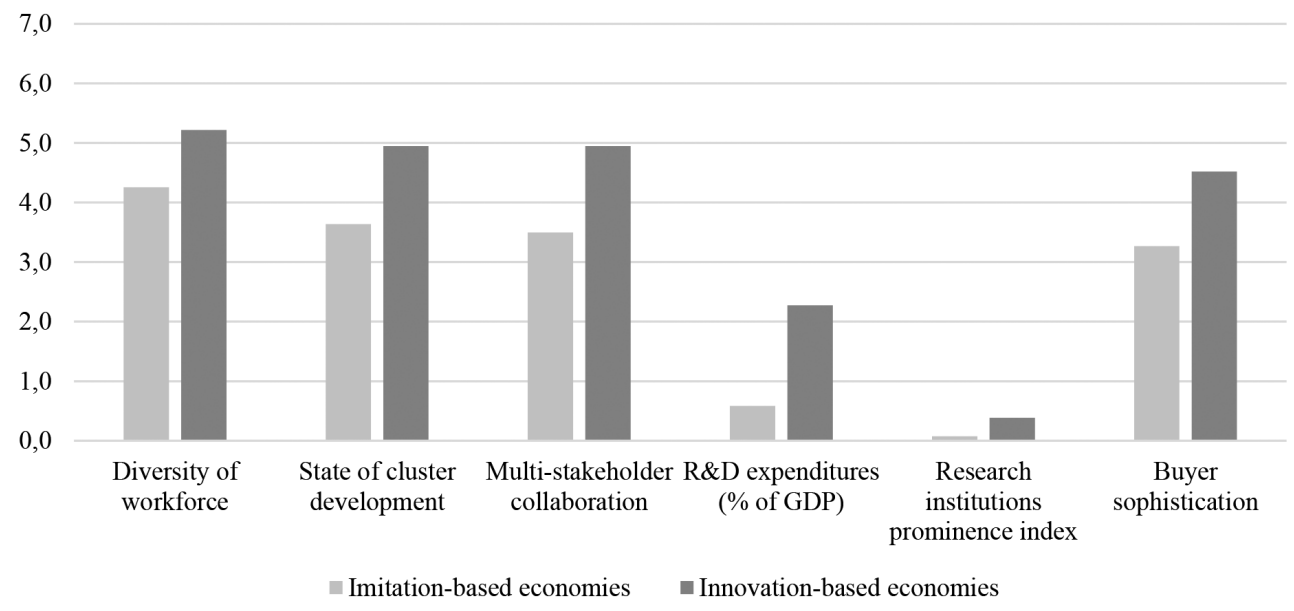

Figure 3: Differences between innovation and imitation-based economies in the innovation capability pillar of the Global Competitiveness Index 4.0

Source: own calculations based on [8]

In the case of seven-stage scale variables, the highest difference between country groups is in R\&D expenditures followed by multi-stakeholder collaboration and the state of cluster development. The R\&D expenditures are important both innovation and adaptation of new technologies, i.e. imitation. The highest value of this ratio is $4,266 \%$ related to Israel followed by Korea with a 4,22 value while the lowest value is approximately 0 . The multi-stakeholder collaboration measures what extent do people collaborate and share ideas within a company so this is an important indicator of knowledge transfer within a company. Clusters are geographic concentrations of firms, so they indicate a spatial form of collaboration and sharing knowledge between economic actors. Analysing the innovation capability pillar, we can conclude that imitation-based economies are lagging behind in knowledge transfer and in innovation output measured by patents and trademarks.

In the next step of the analysis, normal distribution of variables is tested. Based on the Kolmogorov-Smirnov test, there are 60 variables from the 98, which has normal distribution so Independent-Samples $t$ test can be run to compare the means of innovation performance groups. There is another prerequisite of $t$ test, it is the homoscedasticity which is tested by the Levene's test. Equal variances are not assumed in the case of 27 variables from 60 based on this test. In these cases, Welch's t test is used to compare means. As a result of this analysis, there is no significant difference between innovation- and imitation-based economies in 6 variables, such as flexibility of wage determination $(\mathrm{P}=0,818)$, ease of hiring foreign labor $(\mathrm{P}=0,055)$, internal labor mobility $(\mathrm{P}=0,277)$, total tax on labor $(\%)(\mathrm{P}=0,946)$, banks' regulatory cap- 
ital ratio (\% of risk-weighted assets) $(\mathrm{P}=0,654)$ and imports of goods and services (\% GDP) $(\mathrm{P}=0,159)$. These results support that innovation- and imitation-based countries are close to each other in the field of labour market, mainly in labour mobility. Labour market changes induced by technological progress cause labour migration not only within country, but also between country. This mobility occurs in both groups because of the skill and wage asymmetry. The labour market adaptation to the technological changes is required in all country independent from the current technological level. The other two variables related to the financial system and market size highlight that a stable financial market and international trade are also important not only for innovation but also for imitation.

There is no normal distribution in the case of 38 variables $(\mathrm{P}<0,05)$, so the Mann-Whitney $\mathrm{U}$ test is used to compare means. There is no significant difference between innovation- and imitation-based economies in 3 variables, terrorism incidence $(\mathrm{P}=0,593)$; redundancy costs (weeks of salary) $(\mathrm{P}=0,091)$ and credit gap $(\%)(\mathrm{P}=0,928)$. The further 3 variables strengthen the importance of labour market and financial system and highlight the role of institutions.

Summarizing the empirical results, we can conclude that Global Competitiveness Index 4.0 measures well the country-specific characteristics of competitiveness and with this the technological progress in the era of the Fourth Industrial Revolution. Innovation is one of the main elements of competitiveness in this era; countries have to adapt to the challenges created by new technologies. The labour market adaptation is crucial, new skills are required, mobility has been intensified because of skill and wage asymmetry.

\section{CONCLUSION}

In the era of the Fourth Industrial Revolution, when new technologies fundamentally change the operation of the economy, digitization creates opportunities to improve economic efficiency which lead to productivity and economic growth. Technological progress is the driving force of economic growth, but it can be realized by innovation and adaptation of existing technologies, i.e. imitation. Depending on the country's income level, innovation-based growth is associated with higher income level, while imitation fits for lower income level. This research aims to compare the economic performance of innovation- and imitation-based economies in the relevant field of technological progress based on Global Competitiveness Index 4.0. It is assumed that the economic performance of innovation-based countries is better than imitation-based ones in almost every field of competitiveness. Because of this, the research question was in which areas of the Global Competitiveness Index 4.0 there are no significant differences between innovation- and imitation-based economies. The country groups are close to each other in the field of labour market and in some elements of financial system. It was not surprising that the main difference is in the field of innovation capability, mainly in innovation output and knowledge transfer. The other question was whether imitation-based economies seem to be converged to innovation leaders. We can conclude that the group of innovation-based economies are homogenous, but in the imitator cluster there are some countries, e.g. China and Korea who show the signs of catching up to innovation leaders.

\section{ACKNOWLEDGEMENT}

This research is supported by the Hungarian National Talent Program, Nation's Young Talent Scholarship. 


\section{REFERENCES}

[1] Acemoglu, D., Aghion, P., Zilibotti, F. (2006) Distance to frontier, Selection, and Economic growth. Journal of the European Economic Association, 4(1), pp. 37-74.

[2] Barro, R. J., Sala-i-Martin, X. (1997) Technological Diffusion, Convergence, and Growth. Journal of Economic Growth, Vol. 2(1), pp. 1-26.

[3] Basu, S., Weil, D. N. (1998) Appropriate Technology and Growth. The Quarterly Journal of Economics, 113(4), pp. 1025 - 1054.

[4] Csugány J. (2016) A gazdasági, technológiai és intézményi fejlettség összefüggésének empirikus vizsgálata: az innovátor és imitátor országok megkülönböztetése. [Empirical analysis in the context of economic, technological and institutional development: the distinction between innovator and imitator countries]. Competitio, 15(1), pp. $3-21$.

[5] Jerzmanowski, M. (2007) Total Factor Productivity Differences: Appropriate Technology vs. Efficiency. European Economic Review, 51(8), pp. 2080 - 2110.

[6] Schwab, K. (2018) Global Competitiveness Report 2018. World Economic Forum. http:// reports.weforum.org/global-competitiveness-report-2018/

[7] Szalavetz, A. (2010) Innovációvezérelt növekedés? [Innovation-driven growth?] Közgazdasági Szemle, Vol. LVIII., May, pp. 460 - 476.

[8] World Economic Forum (2018) Global Competitiveness Index 4.0 [database] www3.weforum.org/docs/GCR2018/GCI_4.0_2018_Dataset.xlsx 